\title{
Erratum to: 'Interpersonal psychotherapy for depression and posttraumatic stress disorder among HIV-positive women in Kisumu, Kenya: study protocol for a randomized controlled trial'
}

Chinwe Onu ${ }^{1}$, Linnet Ongeri ${ }^{2}$, Elizabeth Bukusi ${ }^{3}$, Craig R. Cohen ${ }^{4}$, Thomas C. Neylan ${ }^{5}$, Patrick Oyaro ${ }^{6}$, Grace Rota ${ }^{6}$, Faith Otewa ${ }^{6}$, Kevin L. Delucchi ${ }^{5}$ and Susan M. Meffert ${ }^{*}$

Unfortunately, the original version of this article [1] contained an error. There was an error in one of the author's affiliations for this publication. Dr Elizabeth Bukusi should only be listed as affiliated with the Department of Obstetrics and Gynecology, University of Nairobi, Kenya.

\begin{abstract}
Author details
${ }^{1}$ School of Medicine, University of California, San Francisco, USA. ${ }^{2}$ Kenya

Medical Research Institute, Nairobi city, Kenya. ${ }^{3}$ Department of Obstetrics and Gynecology, University of Nairobi, Nairobi, Kenya. ${ }^{4}$ Department of Obstetrics and Gynecology, University of California, San Francisco, USA. ${ }^{5}$ Department of Psychiatry, University of California, San Francisco, USA. ${ }^{6}$ Family AIDS Care

Education and Services, Kisumu, Kenya.
\end{abstract}

\section{Received: 14 March 2016 Accepted: 14 March 2016}

Published online: 21 March 2016

\section{References}

1. Onu C, Ongeri L, Bukusi E, Cohen CR, Neylan TC, Patrick O, Rota G, Otewa F, Delucchi KL, Meffert SM. Interpersonal psychotherapy for depression and posttraumatic stress disorder among HIV-positive women in Kisumu, Kenya: study protocol for a randomized controlled trial. Trials. 2016;17:64.

\footnotetext{
* Correspondence: Susan.meffert@ucsf.edu

${ }^{5}$ Department of Psychiatry, University of California, San Francisco, USA

Full list of author information is available at the end of the article
}

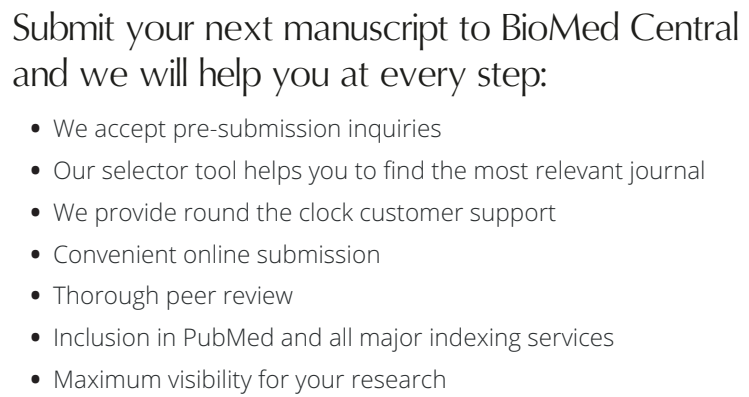

- We accept pre-submission inquiries

- Our selector tool helps you to find the most relevant journal

- We provide round the clock customer support

- Convenient online submission

- Thorough peer review

- Inclusion in PubMed and all major indexing services

- Maximum visibility for your research

Submit your manuscript at www.biomedcentral.com/submit 